\title{
UNTUK APA FILSAFAT HUKUM? PROBLEM METODOLOGI SETELAH DEBAT HART/DWORKIN
}

\author{
Tanius Sebastian*
}

\begin{abstract}
Abstrak: Tulisan berikut membahas pemikiran hukum Anglo-Amerika yang dikenal sebagai filsafat hukum. Dua pokok yang dibahas adalah masalah metodologi dan debat Hart/Dworkin. Inti pertanyaan yang dikaji di sini berkenaan dengan hakikat filsafat hukum. Untuk itu langkah yang diambil adalah dengan menelusuri situasi debat Hart/ Dworkin dan sesudahnya sebagai suatu debat metodologis dan kemudian menggunakannya untuk mengurai pertanyaan tadi. Debat tersebut telah memicu suatu palingan metodologis dalam filsafat hukum analitik yang lantas mengubah fokus dan makna dari kegiatan melakukan filsafat hukum, yakni dari refleksi atas hakikat hukum (dan hubungannya dengan moralitas) menjadi refleksi atas hakikat kegiatan itu sendiri. Berdasarkan telaah kritis terhadap konstelasi dan tren populer dari sejumlah yang ide yang dikembangkan seputar eksistensi debat Hart/Dworkin, termasuk publikasi terbaru teks kuliah Dworkin di Harvard Law Review yang menanggapi Postscript Hart, tulisan ini mengemukakan argumen bahwa wacana filsafat hukum kontemporer menyentuh ranah kritik terhadap dua tesis metafisis, epistemologis, dan etis yang tampak sejajar, yakni dikotomi fakta dengan nilai dan pemisahan hukum dengan moralitas.
\end{abstract}

Kata-kata Kunci: Metodologi filsafat hukum, debat Hart/Dworkin, hukum dan moralitas, filsafat hukum analitik, palingan metodologis, metodologi normatif, metodologi deskriptif.

Abstract: This paper presents an exploration of the Anglo-American legal thought, better known as jurisprudence. A subject matter of it is two interrelated themes, i.e. the problem of methodology and the "Hart/

* Tanius Sebastian, Program Studi Ilmu Hukum, Fakultas Hukum Universitas Katolik Parahyangan, Gedung 2, Jl. Ciumbuleuit No.94, Bandung.E-mail:sebastian.tanius@gmail.com. 
Dworkin debate". The main question addressed here concerning the nature of jurisprudence. It takes an inquiry to the Hart/Dworkin debate situation and its aftermath as a methodological debate and whilst use it to scrutinize that question. The debate has been stirred up the so called methodological turn in analytical jurisprudence, thus vary the focus and meaning of the activity of doing jurisprudence, from a reflection of the nature of law (and its relationship to morality) to a reflection of the nature of that activity itself. Based on the critical examination of constellation and popular trend of some ideas which developed around the existence Hart/Dworkin debate, including the recent publication of Dworkin's lost text in Harvard Law Review replying to Hart's Postscript, this paper argues that the contemporary discourse of jurisprudence attains the significance of a criticism of two kinds of metaphysical, epistemological, and ethical theses which are apparently parallel, i.e. the fact/value dichotomy and the separation of law and morality.

Keywords: methodology of jurisprudence, Hart/Dworkin debate, law and morality, analytic jurisprudence, methodological turn, normative methodology, descriptive methodology.

\section{PENDAHULUAN}

Tulisan ini membahas sebuah tradisi pemikiran hukum AngloAmerika, yakni "filsafat hukum umum" (general jurisprudence), atau yang untuk selanjutnya disebut hanya sebagai filsafat hukum. Dalam

kerangka tersebut, tulisan ini bertolak dari pembicaraan tentang hakikat filsafat hukum yang lantas akan ditelusuri menurut dua tema filsafat hukum yang terkait erat satu sama lain, yakni masalah metodologi dan debat Hart/Dworkin.

Tulisan ini dimotivasi oleh sebuah pertanyaan sederhana berikut: untuk apa filsafat hukum? Pertanyaan macam inilah yang dikemukakan secara implisit oleh Raymond Wacks ketika ia menyatakan bahwa pengalaman belajar filsafat hukum, baik bagi para mahasiswa maupun akademisi profesional, adalah sebuah penderitaan. ${ }^{1}$ Pertanyaan tersebut

1 Raymond Wacks, Understanding Jurisprudence. An Introduction to Legal Theory. Third Edition (Oxford: Oxford University Press, 2012), p. 1. 
mengisyaratkan problematika tentang peran, kedudukan, dan manfaat dari bidang filsafat hukum. Sejauh apa filsafat hukum melekat dengan sifat yang sui generis dan atau esoterik? Bagaimana seharusnya dan apa faedahnya melakukan filsafat hukum atau ber-filsafat atau ber-teori hukum (doing jurisprudence) $?^{2}$

Asal-usul perdebatan metodologis dapat dilacak mundur sampai ke era 1960-an, yakni saat terbitnya sebuah teks yang dianggap kunci bagi perkembangan filsafat hukum modern, yakni buku The Concept of Law, karangan Herbert Lionel Adolphus Hart. ${ }^{3}$ Pada masa itu pula muncul kritik terhadap pemikiran Hart yang terutama berasal dari karyakarya Ronald Dworkin. Demikianlah “debat Hart/Dworkin” memicu suatu palingan metodologis yang mengubah fokus kegiatan berfilsafat hukum dari refleksi tentang hakikat hukum (dan hubungannya yang tercampur atau terpisah dengan moralitas) menjadi refleksi tentang hakikat kegiatan berfilsafat hukum itu sendiri. Dengan reputasi itu, debat Hart/Dworkin mendominasi pembicaraan filsafat hukum, mulai dari tingkat kurikulum fakultas hukum sampai tingkat diskursus kalangan filsuf hukum profesional. ${ }^{4}$

Tulisan ini akan memeriksa teks-teks kunci yang merepresentasikan pemikiran tentang hakikat filsafat hukum sejak dan setelah debat Hart/ Dworkin. Lima puluh tahun sejak debat Hart/Dworkin mengemuka, kini berkembang sejumlah gagasan metodologi filsafat hukum, baik dari pemikir yang meneruskan atau membela, maupun dari mereka yang hendak melampaui atau keluar dari kerangka debat Hart/Dworkin. Pada medio 2017, Harvard Law Review bahkan mempublikasikan teks

2 Lih. Leslie Green, "General Jurisprudence: A 25 $5^{\text {th }}$ Anniversary Essay," in Oxford Journal of Legal Studies 25 (2005): 575.

3 Sean Coyle, Modern Jurisprudence. A Philosophical Guide (Oxford and Portland, Oregon: Hart Publishing, 2014), p. 16.

4 Brian Leiter, "Beyond Hart/Dworkin Debate: The Methodology Problem in Jurisprudence," American Journal of Juriprudence 48 (2003): p. 1; Scott J. Shapiro, “The 'Hart-Dworkin' Debate: A Short Guide for the Perplexed," Michigan Law Working Paper No. 77, March 2007, p. 1. 
transkrip kuliah Dworkin yang berisi tanggapannya terhadap teks Postscript buku The Concept of Law dari Hart. Teks tersebut dapat memberi wawasan baru untuk memahami masalah metodologi filsafat hukum.

Di sini, pembacaan atas tema masalah metodologi dalam situasi debat Hart/Dworkin dan sesudahnya akan memperlihatkan bahwa debat tersebut perlu dipahami sebagai debat metodologis yang memberi sebuah orientasi bagi pengembangan kajian tentang hakikat filsafat hukum. Tema pun tersebut bernilai penting bagi dan dalam studi filosofis. Dengan mendiskusikan secara kritis sejumlah gagasan seputar pertentangan corak metodologi (normatif-evaluatif versus deskriptif), juga hubungan antara hukum dan moralitas, serta antara legalitas dan legitimasi, argumen tulisan ini adalah bahwa filsafat hukum merupakan disiplin filosofis yang berkutat bukan hanya dengan penjelasan tentang makna hukum yang abstrak dan umum, tapi juga tentang perkaitannya dengan moralitas, pengetahuan, dan kebenaran dalam konteks praktik hukum di masyarakat. Dengan merefleksikan debat Hart/Dworkin dan sesudahnya, argumen tersebut menunjukkan pula bahwa pembahasan filsafat hukum kontemporer menyentuh ranah kritik terhadap dua tesis metafisis, epistemologis, dan etis yang tampak sejajar, yakni dikotomi fakta dengan nilai dan separasi hukum dengan moralitas.

Pembahasan tulisan ini disusun sebagai berikut. Pertama, dipaparkan alasan-alasan pentingnya memahami masalah metodologi filsafat hukum. Bagian berikutnya menjelaskan status dari debat Hart/Dworkin dalam kaitannya dengan masalah metodologi tersebut. Setelah itu, diuraikan perihal situasi palingan metodologis pada ranah filsafat hukum. Bagian selanjutnya akan mendiskusikan kontelasi dan tren popular kegiatan berfilsafat hukum yang mengacu pada situasi palingan tersebut. Lantas, akan dijelaskan situasi pasca debat Hart/Dworkin yang mengungkapkan problematika hakikat filsafat hukum berdasarkan teori hukum interpretatif Dworkin. Bagian terakhir adalah penutup yang meringkas inti tulisan ini. 


\section{URGENSI WACANA}

Sebelum menyentuh substansi debat Hart/Dworkin dan sesudahnya, akan dijelaskan dahulu alasan perlunya kita membahas tema perdebatan metodologi. Apa urgensi untuk memikirkan metodologi filsafat hukum? Pada bagian ini hendak dikemukakan bahwa alasannya adalah karena wacana tentang metodologi yang mendominasi pemikiran filsafat hukum Anglo-Amerika. Wacana tersebut mengungkapkan bukan hanya nilai penting atau kelebihan, tapi juga kendala atau kelemahan pemikiran tentang metodologi filsafat hukum. Keberlangsungan wacana tersebut sudah mulai sejak setengah abad yang lalu — terutama yakni yang mengacu pada pernyataan Hart di dalam bagian Preface dari buku The Concept of Law tentang corak proyek filsafat hukumnya- hingga terus meluas sampai hari ini. ${ }^{5}$

Adanya urgensi wacana tentang metodologi filsafat hukum yang dimaksud di sini bukan sekadar menunjuk pada keadaan di mana "semua orang" (telah) mengetahui dan membahasnya. Apabila demikian, urgensi yang dimaksud hanya dimengerti secara permukaan berdasarkan alasan yang menggeneralisasi. Makna sebenarnya muncul karena pengetahuan umum seperti itu adalah justru yang mengaburkan duduk perkara dari metodologi filsafat hukum. Memahami dengan tepat duduk perkara tersebut dapat berguna untuk memahami pertanyaan tentang apa makna dari filsafat hukum.

Nada keluh-kesah seperti yang disampaikan di awal tulisan ini juga disuarakan oleh David Enoch yang ditanggapi secara kritis oleh Julie Dickson. Dickson menyangkal pandangan Enoch yang pada intinya mempertanyakan soal apakah filsafat hukum itu merupakan kajian yang menarik secara filosofis, khususnya tentang dasar mengikat (normativitas) dan dasar keabsahan (validitas) dari hukum. Filsafat hukum, tegas

5 Alex Langlinais and Brian Leiter, "The Methodology of Legal Philosophy," in University of Chicago Law School Public Law E Legal Theory Working Papers No. 407, 2012: 1. Andrew Halpin, "Methodology," in A Companion to Philosophy of Law and Legal Theory, Second Edition, ed. Dennis Patterson (West Sussex: Wiley-Blackwell, 2010), pp. 607. 
Dickson, jelas punya sisi-sisi yang menarik untuk dipelajari secara filosofis sebagai suatu bidang kajian tersendiri. ${ }^{6}$

Berdasarkan hal di atas, tampak bahwa filsafat hukum memiliki karakter sui generis dan esoterik. Filsafat hukum diragukan kegunaan serta kontribusinya sebagai suatu kajian filosofis sehingga dianggap tidak menarik, dibandingkan kajian-kajian seperti etika, meta-etika, dan filsafat atau teori politik yang juga membahas perihal, norma, moralitas, keadilan, dan tema-tema lain terkait hukum. Dalam sejarah pemikiran Barat, anggapan umum bahwa filsafat hukum merupakan kajian yang kurang menarik sebenarnya telah dihadapi oleh Hart, yakni pada saat ia mulai menduduki kursi profesor filsafat hukum di Universitas Oxford. Dari catatan Nicola Lacey, kita dapat melihat bahwa salah satu tantangan Hart di fakultas hukum Oxford pada kisaran akhir Perang Dunia II adalah membuat para murid di sana tertarik mempelajari teori hukum dengan filsafat — dan bukan sejarah atau ilmu-ilmu sosial— sebagai sumber utama pemikirannya. ${ }^{7}$

Gejala-gejala skeptisisme dan sinisme terhadap filsafat hukum di atas mengilustrasikan latar belakang muncul dan menguatnya pewacanaan tentang metodologi filsafat hukum. Dalam sejarah pemikiran hukum Anglo-Amerika, latar belakang tersebut juga ditunjukkan oleh suatu pemicu yang disebut sebagai "palingan metodologis" dalam filsafat hukum berkat debat Hart/Dworkin. Kita akan membahasnya lebih lanjut di bagian berikut. Di sini perlu dijelaskan lebih lanjut soal bagaimana dan sejauh apa gagasan-gagasan tentang metodologi filsafat hukum itu telah sedemikian menguat, menjadi tren, serta kontroversial.

Tidak berlebihan untuk mengatakan bahwa aktivitas berfilsafat hukum masa kini (kontemporer) diramaikan dengan usaha untuk menelaah

6 Julie Dickson, "Why General Jurisprudence is Interesting," in Oxford Legal Studies Research Paper 17 (2017): 1-2. Tulisan Dickson ini menanggapai artikel Enoch berjudul "Is General Jurisprudence Interesting?" yang dipublikasikan dalam situs Social Science Research Network (SSRN).

7 Nicola Lacey, A Life of H.L.A. Hart. The Nightmare and the Noble Dream (Oxford: Oxford University Press, 2004), p. 161-162. 
metodologi. Sejumlah penelitian dari beragam tradisi akademik telah bergulat secara serius dengan pertanyaan mengenai status dan metode ilmiah dari filsafat hukum. ${ }^{8}$ Kendati berasal dari konteks tradisi pemikiran akademik hukum yang berbeda, beberapa pertemuan ilmiah pun berkutat dengan masalah tentang hakikat filsafat hukum. Dari situ muncul berbagai gagasan tentang metodologi. Ketidakjelasan tentang kedudukan filsafat hukum sebagai suatu disiplin ilmiah dapat dikupas, sekalipun tidak tuntas dan masih mengundang banyak perbedaan pandangan.

Aktivitas kalangan ahli hukum ini mengungkapkan bahwa jawaban atas pertanyaan untuk apa filsafat hukum memang bukan dan tidak harus berupa sesuatu yang pasti atau final. Satu hal yang menarik adalah pandangan Andrew Halpin yang telah mengkritisi kaitan antara wacana metodologi dan hakikat filsafat hukum. Halpin melihat bahwa proses dan hasil pembahasan hal yang disebut pertama telah bersifat eksklusif dan elitis, terpisah dari problem hukum yang paling nyata di masyarakat, sehingga tidak ada manfaatnya bagi pengembangan hal yang disebut belakangan itu. Menurutnya, lapangan metodologi filsafat hukum menikmati posisi tertinggi dalam puncak piramida struktur pemikiran hukum. ${ }^{9}$ Dengan begitu, wacana metodologi menjadi berdiri sendiri jauh berada di atas lapangan praktik hukum yang berposisi paling bawah di piramida tersebut. Di antara kedua lapangan tersebut, terseliplah lapangan teori hukum yang menjadi berstatus "sekadar" sebagai objek kajian metodologi yang belum tentu pula terkait langsung dengan masalah

8 Dari latar belakang tradisi akademik perbandingan hukum (comparative law), Mark van Hoecke dan kawan-kawan telah menyelenggarakan lokakarya pada tahun 2009 di Universitas Tilburg pada 2009. Lih. Mark van Hoecke ed., Methodologies of Legal Research. Which Kind of Method for What Kind of Discipline? (Oxford and Portland, Oregon: Hart Publishing, 2011). Sebelumnya, bahkan, pada tahun 2002, telah berlangsung lokakarya serupa yang diadakan oleh para pengajar dan praktisi hukum dari tradisi filsafat hukum analitik (analytical jurisprudence) di Universitas Queen Mary, Belfast. Lih. Sean Coyle and George Pavlakos eds., Jurisprudence or Legal Science? (Oxford and Portland, Oregon: Hart Publishing, 2005).

9 Andrew Halpin, “The Methodology of Jurisprudence: Thirty Years Off the Point," in Canadian Journal of Law and Jurisprudence 1 (January 2006): 67-68. 
praktis hukum. Dengan kata lain, berdasarkan pandangan Halpin, metodologi bukan atau tidak menyediakan jawaban bagi pertanyaan untuk apa filsafat hukum, tapi justru menjadi sumber masalah yang menunjukkan kegagalan pemikiran filsafat hukum perihal bagaimana teori tentang hukum perlu dibangun.

Kritik Halpin di atas bukanlah tanpa jalan keluar. Ia sendiri memberi gagasan-gagasan solutif dengan mempertimbangkan antusiasme terhadap metodologi yang sudah meluas sedemikian rupa dalam dunia teori hukum. Dalam tulisannya yang lain, ia menunjukkan bahwa telaah atas metodologi memiliki sejumlah peranan untuk memahami hakikat filsafat hukum. ${ }^{10}$ Inti dari ketujuh peranan tersebut dapat dipahami dari kata-kata kunci uraian Halpin, yakni bahwa metodologi filsafat hukum membantu: untuk mengenali hakikat, karakter, serta keterbatasan dari bidang filsafat hukum; untuk membuktikan kehandalan suatu pendekatan atau posisi teoretis yang satu dari yang lain; dan, untuk menyematkan kredibilitas disiplin filsafat hukum sehingga dapat diperbandingkan atau bahkan diasimilasikan dengan disiplin intelektual yang lain.

Penilaian dari Halpin di atas menunjukkan dua hal. Pertama, pada satu sisi, bahwa pembicaraan tentang metodologi memiliki kekurangan atau kelemahan. Kedua, pada sisi lain, bahwa wacana metodologi memiliki kontribusi positif bagi upaya memahami secara lebih mendalam perihal maksud dan tujuan dari filsafat hukum sebagai suatu disiplin dan penelusuran intelektual.

Kontroversi seputar pengembangan ide-ide metodologi filsafat hukum di atas tampak menandakan urgensi dari pewacanannya. Akan tetapi, dalam gegap gempita yang demikian masih saja terserak keraguan tentang makna metodologi. Metodologi seperti apa yang paling

10 Halpin memaparkan adanya tujuh peranan dari telaah atas metodologi filsafat hukum bagi pemahaman atas kedudukan, hakikat, karakter, dan keterbatasan bidang filsafat hukum. Lih. Andrew Halpin, "Methodology," in A Companion to Philosophy of Law and Legal Theory, ed. Dennis Patterson (West Sussex: Wiley-Blackwell, 2010), p. 607. 
tepat? Apakah memang tersedia metodologi yang demikian? Aaron J. Rappaport mensinyalir adanya kebingungan semacam ini. Dalam pandangan Rappaport, metodologi filsafat hukum bagaimana pun juga bersifat instrumental. Artinya, perwujudan metodologi tersebut bergantung pada capaian-capaian yang dikehendaki oleh sang teoretikus hukum. Apabila pandangan ini diletakkan dalam kerangka pokok bahasan tulisan ini, upaya menjawab pertanyaan untuk apa filsafat hukum perlu mempertimbangkan capaian teoretis dari kegiatan ber-filsafat hukum. Dengan kata lain, memahami hakikat filsafat hukum dapat dibantu dengan memahami metodologi filsafat hukum.

Sampai di sini telah dipaparkan berbagai pertimbangan yang menunjukkan urgensi wacana metodologi filsafat hukum dilihat dari dinamika intelektual dunia pemikiran hukum saat ini. Terdapat minat disertai kebutuhan akan cara pandang metodologis terutama demi memahami dan membela status filsafat hukum sebagai disiplin dan kajian filosofis yang bernilai.

Seperti yang telah disinggung di atas, terdapat suatu latar belakang historis dari pewacanaan metodologi dalam pemikiran hukum AngloAmerika. Latar belakang tersebut menunjuk pada situasi yang disebut sebagai debat Hart/ Dworkin. Arti penting dari pembicaraan metodologi dalam kaitannya dengan upaya memahami hakikat filsafat hukum akan ditempatkan dalam kerangka debat Hart/Dworkin tersebut. Dengan begitu, kita dapat membedah pokok-pokok masalah metodologi filsafat hukum. Dalam debat Hart/Dworkin, masalah tersebut berupa perdebatan yang muncul akibat adanya palingan metodologis dalam perkembangan filsafat hukum.

\section{MENIMBANG DEBAT HART/DWORKIN}

Pada bagian ini hendak dijelaskan perihal pokok-pokok dari masalah perdebatan metodologis filsafat hukum. Mengapa perdebatan tersebut muncul dan apa yang menjadikannya problematik? Ada dua pokok yang dapat membantu kita untuk menjelaskan pertanyaan tersebut. 
Pokok pertama adalah narasi tentang situasi debat Hart/Dworkin. Pokok kedua adalah sejumlah posisi-posisi yang membentuk peta teoretis dari perdebatan metodologis. Uraian kedua pokok tersebut terkait satu sama lain karena adanya suatu palingan metodologis dalam tradisi filsafat hukum analitik.

Pembahasan pada bagian ini adalah sebagai berikut. Pertama, akan ditelusuri kaitan antara debat Hart/Dworkin dan urgensi wacana metodologi filsafat hukum. Pembahasan debat Hart/Dworkin di sini tidak dimaksudkan untuk memberi penilaian (dengan mendukung atau menyanggah) terhadap salah satu atau beberapa kubu dalam konstelasi perdebatan. Situasi debat Hart/Dworkin di sini akan diacu sebagai sarana untuk menunjukkan adanya perdebatan metodologis filsafat hukum. Melalui kerangka debat Hart/Dworkin, terungkap bahwa pertanyaan utama dalam perdebatan metodologis, yakni corak filsafat hukum seperti apa yang mungkin? Untuk memberikan penjelasan yang lebih ternuansa, kemudian akan dijelaskan suatu gambaran besar berupa konteks tradisi filsafat hukum analitik yang mengalami palingan metodologis. Bertolak dari uraian tentang perkaitan tersebut, selanjutnya akan dipaparkan sejumlah posisi pemikiran yang pada mulanya mengacu debat Hart/Dworkin, namun lantas menghasilkan diskusi produktif tentang kemungkinan-kemungkinan corak filsafat hukum. Dalam diskusi tersebutlah tergambarkan suatu peta teoretis tentang metodologi filsafat hukum yang berusaha melampaui atau bahkan meninggalkan debat Hart/Dworkin. Kendati demikian, pengembangan peta teoretis itu mampu menampilkan keutamaan metodologi dalam menjelaskan hakikat filsafat hukum.

Debat Hart/Dworkin telah menjadi satu tema eksklusif yang menyita perhatian dunia filsafat hukum, terutama di kalangan akademik. ${ }^{11}$ Namun apa itu sebenarnya debat Hart/Dworkin? Pertanyaan ini bukanlah sekadar suatu keragu-raguan atau pun retorika belaka. Sebab ada ber-

11 Ada yang mencatat bahwa dalam mesin pencari Google Scholar dapat ditemukan sekitar 1.560 artikel akademik yang membahas atau pun menyinggung istilah "HartDworkin." Tommaso Pavone, "A Critical Adjudication of the Hart-Dworkin Debate," 
agam gambaran tentang debat Hart/Dworkin. Secara kronologis debat Hart/Dworkin dapat diidentifikasi dari penerbitan teks-teks kunci Hart dan Dworkin yang memperlihatkan bahwa keduanya saling menanggapi kritik yang diajukan masing-masing. ${ }^{12}$ Secara karikatural, kronologi berdasarkan penerbitan itu dimulai dari buku Hart, The Concept of Law yang lantas dikritik oleh Dworkin melalui buku-bukunya, Taking Rights Seriously dan Law's Empire. Tanggapan Hart atas kritik Dworkin lantas dituangkan di bagian Postscript edisi kedua bukunya itu.

Menurut kronologi publikasi teks Hart dan Dworkin, perdebatan antar keduanya pertama-tama dipicu oleh pernyataan Hart tentang proyek filsafat hukum-nya. Dalam bagian Preface bukunya (seperti yang telah disinggung di bagian sebelumnya) dan yang ditegaskan lebih lanjut di bagian Postscript, Hart mengklaim bahwa analisis teori hukum yang ia tawarkan bercorak "umum" dan "deskriptif."13 Di samping perihal corak teori hukum tersebut, menurut Postscript Hart perbedaan pendapatnya dengan Dworkin juga menyangkut beberapa hal lain, seperti misalnya tentang makna "diskresi" dan "konsep aturan." Namun, berdasarkan karya-karya Dworkin, pokok perdebatan yang dimaksud bersifat dinamis seturut perkembangan pemikiran Dworkin.

Dalam buku terakhirnya, dapat dibaca bahwa Dworkin memposisikan teori hukum yang memandang dualisme hukum dan moral (yakni teori yang positivis dan teori yang anti-positivis) sebagai lawan tanding utama dari konsepsi teori hukumnya. ${ }^{14}$ Sejauh dalam arti itu, debat Hart/ Dworkin tampak bukan lagi semata berlangsung antara Hart seorang diri di satu sisi dan Dworkin di sisi lain. Hugh Baxter menunjukkan bahwa gagasan utama dalam buku Justice for Hedgehogs mengemukakan

https://scholar.princeton.edu/sites/default/files/tpavone/files/hartdworkin_debate_critical_review.pdf, diakses pada 31 Agustus 2017.

12 Tommaso Pavone, “A Critical Adjudication of the Hart-Dworkin Debate," p. 1.

13 H.L.A. Hart, The Concept of Law. Second Edition (Oxford: Clarendon Press, 1994), p. v, 239-240.

14 Ronald Dworkin, Justice for Hedgehogs (Cambridge, Masschusetts, London: The Belknap Press of Harvard University Press, 2011), p. 400-401. 
revisi dan reorientasi bagi konsepsi hubungan hukum dan moralitas yang selama ini dipahami Dworkin dalam berhadapan dengan sejumlah posisi atau aliran pemikiran filsafat hukum. ${ }^{15}$

Padahal, pandangan kritis Dworkin dalam buku Taking Rights Seriously secara terfokus ditujukan pada konsepsi Hart tentang esensi hukum sebagai aturan. Dalam gambaran kronologis seperti ini, timbul kemungkinan implikasi bagi tradisi pemikiran filsafat hukum AngloAmerika, yakni keragu-raguan tentang eksistensi debat Hart/Dworkin. Apakah betul telah terjadi debat antara keduanya dan karenanya adakah manfaat mempelajari debat tersebut?

Jelas bahwa debat Hart/Dworkin dalam gambaran kronologis di atas menyisakan suatu teka-teki besar. Scott J. Shapiro, misalnya, mesti mengerahkan tenaga pikirannya untuk mengklarifikasi bahwa debat tersebut memang dan telah berlangsung di tengah kerumitan diskursusnya, termasuk seperti yang tampak dari dan diakibatkan oleh gambaran kronologis itu. Debat Hart/Dworkin, baginya, tampil dalam rupa pertentangan argumen atas sebuah masalah kunci filsafat hukum, yakni hubungan antara legalitas dan moralitas. ${ }^{16}$ Dalam gambaran Shapiro, baik Hart maupun Dworkin melancarkan pendiriannya masingmasing serta melontarkan kritik satu sama lain yang lantas diramaikan oleh kubu-kubu yang mengikuti atau memodifikasi pandangan salah satu pihak. Hal ini juga dibuktikan oleh terbitnya buku kumpulan tulisan dari para komentator Hart dan Dworkin yang khusus mengkaji bagian Postscript Hart. ${ }^{17}$ Situasi debat Hart/Dworkin menurut gambaran demikian lebih tepat dimengerti sebagai suatu pengkonfigurasian (ulang dan terus-menerus) pandangan tentang hubungan hukum dan moralitas, baik yang berasal maupun yang terinspirasi dari teori Hart dan Dworkin.

15 Hugh Baxter, “Dworkin 'One-System' Conception of Law and Morality.” Boston University Law Review 90 (2010): 857.

16 Scott J. Shapiro, “The 'Hart-Dworkin' Debate,": 5.

17 Lih. Jules L. Coleman ed., Hart's Postscript. Essays on the Postscript of The Concept of Law (Oxford: Oxford University Press, 2001). 
Terdapat kontroversi tentang tema debat Hart/Dworkin. Namun tampaknya tema hubungan hukum dan moralitaslah yang mendominasi penarasian debat Hart/Dworkin. Hubungan hukum dan morali-tas sendiri merupakan tema klasik yang senantiasa menjadi pembuka atau acuan diskursus filsafat hukum. Brian Bix meringkas isi diskursus tersebut sebagai berikut. "Selama berdekade-dekade, kalau bukan berabad-abad, diskusi di kelas Filsafat Hukum seringkali dimulai dengan pertanyaan: 'Apa itu Hukum?' Lantas, biasanya dalam diskusi disebutkan beragam definisi yang konvensional dan juga yang tidak biasa (tergantung pada selera dan minat dari sang pengajar atau editor buku pelajaran)..."18 Dari situ, masih menurut Bix, pembelajaran filsafat hukum berlanjut dengan membahas karya para teoretikus, termasuk Hart dan Dworkin, yang mengungkapkan topik masalah "hakikat hukum" (the nature of law), yakni perihal elemen-elemen esensial alias penting yang membentuk entitas yang disebut "hukum." Jadi, tema klasik filsafat hukum menunjuk pada pertanyaan-pertanyaan tentang karakteristik dari hukum dan status hubungannya dengan moralitas. ${ }^{19}$

Debat Hart/Dworkin dipandang berdasarkan tema hakikat hukum dan hubungannya dengan moralitas di atas sejauh karena pengaruh klaim kontroversial dari "tesis separasi." ${ }^{20}$ Klaim ini berasal dari positivisme hukum yang juga didukung oleh Hart. Maka, segera tampak bahwa potret debat Hart/Dworkin merupakan pertentangan antara positivisme hukum yang memisahkan hukum dari moralitas, di satu sisi, dan aliran teori hukum kodrat yang menentang tesis separasi tersebut, di sisi lain.

Tapi apa asal-muasal konstruksi berpikir dari tema klasik seperti itu? Dari konteks apa sebenarnya kemunculan debat Hart/Dworkin? Pertanyaan ini menuntut suatu upaya menelusuri sejarah tradisi pemi-

18 Brian Bix, “Methodology in Jurisprudence.” JOTWELL (May 19, 2010), http:// juris.jotwell.com/methodology-in-jurisprudence/, diakses pada 6 September 2017.

19 Mark Tebbit, Philosophy of Law. An Introduction (London and New York: Routledge, 2005), hlm. 3.

20 Mark Tebbit, Philosophy of Law, hlm. 3. 
kiran. Dengan itu, sekiranya makna dari debat Hart/Dworkin dapat menjadi makin jelas. Debat tersebut sesungguhnya menyangkut tema pertentangan metodologi filsafat hukum. Dennis Patterson menggambarkan debat Hart/Dworkin sebagai debat metodologi dalam filsafat hukum, dengan topik sentral tentang pertanyaan corak dari filsafat hukum: apakah filsafat hukum deskriptif itu mungkin? Seperti yang dituliskan Patterson, "Hart, para positivis pada umumnya, menyatakan bahwa deskripsi tanpa evaluasi (penilaian) itu mungkin. Berhadapan dengan Hart, Dworkin dan John Finnis bersikeras bahwa evaluasi merupakan unsur yang niscaya perlu ada dalam analisis filsafat hukum." 21

Debat Hart/Dworkin sebagai debat metodologis memiliki konteks latar belakang pemikiran yang khas, yakni yang mengacu pada tradisi "filsafat hukum analitik." Sejumlah komentator dan teoretikus hukum Anglo-Amerika kontemporer mensinyalir bahwa situasi debat Hart/ Dworkin dalam tradisi tersebut tidak lepas dari terjadinya situasi palingan metodologis. Bagian berikut memaparkan lebih lanjut situasi tersebut.

\section{SITUASI PALINGAN METODOLOGIS}

Pokok tentang debat Hart/Dworkin sebagai debat metodologis kiranya makin jelas apabila kita memeriksa situasi palingan metodologis yang terjadi dalam tradisi filsafat hukum analitik. Bagian berikut hendak mendeskripsikan situasi palingan tersebut dengan berfokus secara berurutan pada tiga poin utama, yakni perumusan status disiplin filsafat hukum, problem yang terkandung dalam status tersebut, dan macammacam kelompok gagasan yang berkembang dari problem tersebut.

Dalam paparannya tentang kajian hakikat hukum dalam perkembangan teori-teori hukum, Andrei Marmor mengemukakan bahwa palingan metodologis merupakan tantangan bagi filsafat hukum pada

21 Dennis Patterson, "Notes on the Methodology Debate in Contemporary Jurisprudence. Why Sociologist Might be Interested" Law and Sociology, Vol. 8, pp. 254-258, May 9 (2006). https:/ / papers.ssrn.com/sol3/papers.cfm?abstract_id=848984, diakses pada 14 November 2017. 
umumnya dan teori positivisme hukum pada khususnya. Bagi Marmor, kemunculan wacana palingan metodologis tersebut adalah berkat publikasi karya Dworkin, yakni buku Law's Empire. Apabila sebelumnya disinggung bahwa pertanyaan tentang metodologi filsafat hukum tak adalah pertanyaan tentang langkah-langkah melakukan atau ber-filsafat hukum, Marmor merinci pertanyaan tersebut ke dalam dua kerangka berikut $^{22}$ (1) Apa sasaran yang hendak ditangkap oleh teori-teori hukum pada tatanan pertama (first order)? Pertanyaan ini menyoal tujuan dan kriteria kesuksesan dari teori-teori filosofis mengenai hakikat hukum; (2) Apakah teori-teori hukum pada tatanan pertama itu secara inheren atau niscaya bersifat evaluatif ataukah murni deskriptif? Pertanyaan ini menyoal peran evaluasi dalam metodologi filsafat hukum.

Kerangka pertanyaan Marmor di atas berkenaan dengan status disiplin filsafat hukum. Sebuah ilustrasi dapat membantu untuk lebih menangkap maksud kerangka tersebut. Ilustrasi yang dikemukakan berikut diambil dari praktik hukum perizinan dan pertanahan. ${ }^{23}$ Dalam administrasi pertanahan di kota Bandung, kewenangan untuk memberikan dokumen izin berada di tangan dinas-dinas pemerintah kota. Namun, peraturan perundangan tentang prosedur dan penetapan izin tersebut senantiasa berganti seiring dengan perubahan kedudukan, alur birokrasi, dan kebijakan dinas-dinas. Lebih lanjut, perubahan tata administrasi tersebut adalah akibat dari perubahan pemimpin alias kepala daerah. Diketahui bahwa dalam praktik kini terdapat banyak bangunan yang didirikan di atas tanah-tanah kota Bandung yang tidak memiliki dokumen izin.

Dengan penyederhanaan dan eklektisisme, maksud ilustrasi itu adalah untuk menjelaskan artikulasi pemikiran menurut kerangka

22 Andrei Marmor, “The Nature of Law." Stanford Encyclopedia of Philosophy (2015). https:/ /plato.stanford.edu/entries/lawphil-nature/, diakses pada 14 November 2017.

23 Tentu ilustrasi ini mengandung bias serta simplifikasi logika hukum karena tidak mengindahkan faktor perbedaan tradisi hukum dan sistem hukum antara negara Indonesia (civil law Eropa-Kontinental) dan negara-negara dunia Anglo-Amerika yang bercorak common law. Sebagai penjelasan tentang faktor-faktor tersebut, lihat: Ratno Lukito, Tradisi Hukum Indonesia (Cianjur: IMR Press, 2013). 
pertanyaan palingan metodologis. Terkait pertanyaan pertama, sebuah teori filosofis tentang problematika tata pemerintahan dapat menelusuri makna hukum; bahwa hukum bukan lagi seperangkat aturan tertulis yang dibuat oleh otoritas (eksekutif dan legislatif, utamanya). Bahkan teori filosofis tersebut dapat mengajukan klaim bahwa pembelajaran hukum yang bersumber dari peraturan atau regulasi merupakan pembelajaran yang tidak relevan. Sebab, regulasi dan semacamnya tunduk pada instruksi pejabat tertinggi di pemerintahan yang bisa berganti dalam setiap periode pemilihan umum.

Penjelasan di atas memperlihatkan bahwa teori atau filsafat hukum yang dikemukakan beranjak dari masalah substantif di bidang hukum perizinan dan pertanahan. Inilah yang dimaksud dengan istilah tatanan pertama. Perhatian utama dari upaya meneorikan seperti itu adalah pada pembuktian dan atau penyusunan argumen-argumen yang menyokongnya. Tekanannya adalah pada sasaran dari teori tentang makna hukum itu sehingga dapat dianggap benar, diterima, dan seterusnya.

Terkait pertanyaan kedua, teori filosofis tentang makna hukum tersebut memunculkan pertanyaan bagi sang pencetusnya: Apakah ia cukup menyatakannya demikian atau ia mengajukan argumen tentang yang harus dilakukan atau dikerjakan dalam carut-marut administrasi izin pertanahan tersebut? Dalam kerangka Marmor, pertanyaan yang disebut pertama menampilkan langkah melakukan filsafat hukum yang deskriptif, sementara yang lain adalah langkah yang normatif.

Marmor juga berpandangan bahwa pengkerangkaan dua pertanyaan palingan metodologis di atas tak lain memperlihatkan adanya perdebatan tentang hakikat filsafat hukum. Pokok ini dapat dijelaskan dengan ringkasan contoh dari Marmor berikut. ${ }^{24}$ Pada permulaan musim panas tahun 2008, sebuah papan elektronik di pinggir jalan tol California bertuliskan sebuah pesan: "Tangan Bebas dari Telepon, 1 Juli, Ini adalah Hukumnya!" Minat seorang filsuf hukum ketika menjumpai pesan

24 Andrei Marmor, Philosophy of Law (Princeton and Oxford: Princeton University Press, 2011), hlm. 1-2. 
normatif itu adalah pada dua hal. Pertama, filsuf hukum mempertanyakan "syarat-syarat yang membentuk keabsahan legal" (conditions of legal validity). Kedua, dan ini terkait erat dengan yang pertama, filsuf hukum memikirkan alasan-alasan yang membuat hukum ditaati atau alasan yang melandasi bahwa keharusan taat akan ketentuan hukum (conditions of legal normativity). Menurut Marmor, filsafat hukum sebagai kegiatan memaknai hakikat hukum mengacu pada refleksi keabsahan dan normativitas legal tersebut. Dengan adanya palingan metodologis, fokus kegiatan filsafat hukum adalah pada pemaknaan kegiatan itu sendiri.

Uraian di atas menunjukkan bahwa palingan metodologis merupakan wacana yang berkembang dari segi gagasan mengenai status disiplin filsafat hukum. Namun sebenarnya wacana tersebut memiliki konteksnya. Melihat kontekstualitas tersebut penting karena dua alasan. Pertama, untuk mengkaitkan palingan metodologis dengan latar belakang historis pemikiran tokoh-tokoh kunci filsafat hukum Anglo-Amerika. Kedua, untuk mengungkapkan lebih lanjut sejumlah problematika kunci dari kegiatan memaknai hakikat kegiatan filsafat hukum itu sendiri.

Situasi palingan metodologis dalam filsafat hukum berakar dari konteks tradisi filsafat hukum analitik. Kita dapat memahaminya dari gerakan arus pemikiran yang membentuk tradisi tersebut. Menurut Coleman, hingga akhir kurun 1980an, gerakan filsafat hukum analitik berkecimpung pada wilayah substantif. ${ }^{25}$ Dalam wilayah ini, fokus filsafat hukum analitik adalah kegiatan mengkaji secara filosofis tematema seperti hakikat hukum, hubungan hukum dengan moralitas, serta hubungan ketentuan dan sistem hukum. Maka, filsafat hukum pertamatama dipandang sebagai kegiatan memikirkan, meneliti, dan mengungkapkan makna esensial dari hukum. Tapi, bagaimanakah melakukan kegiatan berfilsafat hukum seperti itu? Bagaimana sesungguhnya karakter filosofis dari usaha pemaknaan esensi hukum tersebut? Coleman menuliskan bahwa berkat gagasan Hart kajian filsafat hukum analitik

25 Jules Coleman, “Analytic Jurisprudence.” Encyclopedia of Philosophy (2006) http:// www.encyclopedia.com/humanities/encyclopedias-almanacs-transcripts-andmaps/analytic-jurisprudence, diakses pada 21 November 2017. 
didominasi oleh metode analisis konseptual, yakni langkah-langkah menganalisis konsep-konsep hukum, juga konsep-konsep yang terkait dengannya (misalnya "kewajiban" dan "otoritas"), dan keterkaitan antara keduanya itu. ${ }^{26}$

Filsafat hukum analitik lantas bergerak ke wilayah metodologis seiring dengan muncul dan berkembangnya kritik terhadap metode analisis konseptual Hart. Berdasarkan paparan Coleman dan refleksi atas pengembangan disiplin filsafat hukum, tampak bahwa pergerakan tersebut ditandai oleh dua hal, yakni suatu konstelasi dan tren populer dari berbagai karya tentang bagaimana merumuskan teori hukum. Keduanya itu menunjukkan adanya keberagaman metode kajian filosofis atas hakikat hukum atau, setidaknya, terdapat pengakuan terhadap keberagaman tersebut. Dalam pandangan Leslie Green, tendensi pluralisme metodologi tersebut mengemukakan penjelasan tentang masalah ketiadaan konvergensi pandangan dalam studi tentang hakikat hukum, khususnya setelah tonggak pemikiran filsafat hukum modern ditancapkan oleh Hart. ${ }^{27}$

Berdasarkan paparan di atas, tampak bahwa situasi palingan metodologis merupakan hasil atau dampak dari gerakan yang menanggapi secara kritis pendekatan analitis-konseptual Hart terhadap hakikat hukum. Bagaimana pun, pengertian seperti muncul pada aras permukaan dari konstelasi dan tren popular pembahasan metodologi filsafat hukum. Dalam keduanya itu, seperti yang dikemukakan baik dalam catatan Coleman maupun penelusuran Green, terlihat sejumlah versi gagasan metodologis dari tokoh-tokoh teoretikus hukum, antara lain John Finnis dan Stephen Perry.

Namun sesungguhnya masih terdapat pengertian lain di balik aras permukaan tersebut. Kita dapat melihatnya dengan kembali pada pertimbangan tentang debat Hart/Dworkin, yakni bahwa pertarungan

26 Jules Coleman, “Analytic Jurisprudence."

27 Leslie Green, “General Jurisprudence: A 25 ${ }^{\text {th }}$ Anniversary Essay,": 575. 
gagasan metodologis tersebut juga berkaitan dengan komitmen tiap tokoh (masing-masing dalam derajat tertentu) kepada teori atau paham filsafat hukum arus utama, seperti positivisme hukum, hukum kodrat, dan realisme hukum. Maka, dalam arti tertentu palingan metodologis tak lepas dari perhatian pada hubungan hukum dengan moralitas. ${ }^{28}$ Pokok ini berhubungan langsung dengan kerangka debat Hart/Dworkin di bagian sebelumnya.

\section{KONSTELASI DAN TREN POPULER METODOLOGI}

Mengacu pada kerangka tersebut di atas, paparan berikut ini akan mempertimbangkan konstelasi dan tren populer dalam situasi palingan metolodogis. Dalam situasi tersebut, ada tiga sosok yang memiliki pengaruh yang serius melalui karyanya masing-masing, yakni Coleman, Dickson, dan Brian Leiter. Pandangan ketiganya ini penting karena mereka adalah elemen-elemen dari gerakan palingan filsafat hukum analitik sekaligus memiliki (dan tentu mengembangkan) komitmen teoretis mengenai hubungan hukum dengan moralitas.

Ada dua poin yang menjadi benang merah dari tiga pemikir di atas. Pertama, inti pandangan Coleman, Dickson, dan Leiter memunculkan gagasan tentang tolok ukur melakukan aktivitas berfilsafat hukum. ${ }^{29} \mathrm{Di}$ situ, penyelidikan metodologi filsafat hukum berpusat pada pertanyaan tentang bagaimana merumuskan teori yang sesuai dengan tolok ukur (sukses, benar, adekuat, dan seterusnya). Kedua, gagasan metodologis dari ketiganya tampak paralel dengan teori arus utama tentang hubu-

28 Bdk. Mark Tebbit, Philosophy of Law, hlm. 34. Tebbit mengemukakan klaim yang lebih kuat, yakni bahwa perdebatan metodologi filsafat hukum pun tak dapat dilepaskan dari perdebatan tentang hubungan hukum dan moralitas, sebagaimana yang tampak dari debat di antara pemikiran hukum kodrat, positivisme hukum, dan realisme hukum.

29 Lih. misalnya: Julie Dickson, Evaluation and Legal Theory (Oxford and Portland, Oregon: Hart Publishing, 2001); Brian Leiter and Matthew X. Etchemendy, "Naturalism in Legal Philosophy." Standford Encyclopedia of Philosophy (2017), https:// plato.stanford.edu/entries/lawphil-naturalism/, diakses pada 6 Desember 2017; Brian Leiter, "Beyond Hart/Dworkin Debate: The Methodology Problem in Jurisprudence;" Jules Coleman, "Analytic Jurisprudence." 
ngan hukum dengan moralitas. Coleman dan Dickson mengikuti teori hukum yang dikembangkan Joseph Raz yang tak lain adalah eksponen dari variasi positivisme hukum (dengan komitmen pada pemisahan hukum dari moralitas), yakni "positivisme hukum halus" (soft legal positivism) dan "positivisme hukum kasar" (hard legal positivism). ${ }^{30}$ Sementara, Leiter berada pada jalur naturalisme (dalam wacana epistemologi dan filsafat ilmu) yang berkomitmen pula pada realisme hukum yang mengusung metode ilmu-ilmu sosial.

Pembahasan di sini akan dibatasi lebih lanjut pada pandangan Coleman dan Dickson. Dengan mensituasikan penelusuran Coleman dan Dickson tentang metodologi dalam rangka mengartikulasikan pengaruh debat Hart/Dworkin, pembahasan ini hendak pula mengemukakan bentuk-bentuk mutakhir dari refleksi kegiatan berfilsafat hukum yang menarik konsekuensi-konsekuensi palingan metodologis. Akan ditunjukkan bahwa bentuk-bentuk mutakhir ini memperlihatkan dimensi yang berbeda dari konstelasi dan tren populer pemikiran sederet tokoh yang telah disebut di atas. ${ }^{31}$ Kita akan melihat bahwa perbedaan

30 Variasi atau jenis-jenis positivisme hukum ini dikembangkan berdasarkan pertahanan atau pembelaan teori Hart dari kritik Dworkin. Karena keterbatasan tempat, di sini tidak dibahas secara lebih rinci mengenai asal-usul dan definisi dua variasi tersebut. Sebagai catatan, dua istilah variasi positivisme hukum ini dalam pembahasan debat Hart/Dworkin dan metodologi filsafat hukum seringkali dipertukarkan dengan istilah lain, yakni positivisme hukum inklusif dan eksklusif. Jadi, pengertian positivisme halus disejajarkan dengan positivisme inklusif. Sebaliknya, positivisme kasar sejajar dengan yang eksklusif. Coleman sendiri termasuk ke dalam kelompok yang mendukung variasi yang disebut pertama. Scott Shapiro, "The 'Hart-Dworkin' Debate,": 18-26. Brian Leiter, "Beyond the Hart/Dworkin Debate,": 11-15. Pandangan Coleman tentang distingsi sejumlah versi dari tesis positivisme, baik yang dianggap mampu maupun tidak, dalam menangkal kritik Dworkin, lihat: Jules Coleman, "Negative and Positive Positivism," The Journal of Legal Studies 11 (Jan., 1982): 139164.

31 Selain gagasan metodologi dari Coleman, Dickson, Leiter, Finnis, Perry, di sini dapat ditambahkan sumbangsih pemikiran yang dapat ditemukan dari jalur akademis yang mendialogkan studi filsafat hukum (analitik) dengan bidang teori-teori sosial, antara lain karya-karya Brian Z. Tamanaha, Roger Cotterrell, dan Andrew Halpin. Brian Z. Tamanaha, A General Jurisprudence of Law and Society (Oxford: Oxford University Press, 2001); Roger Cotterrell, “The Sociological Concept of Law." Journal of Law and Society 10 (1983): 241-255; Nicole Roughan and Andrew Halpin ed., In Pursuit of Pluralist Jurisprudence (Cambridge: Cambridge University Press, 2017). 
tersebut terletak pada aspek-aspek pengembangan tripartit teori hukum Hartian-positivisme hukum-analisis konseptual.

Dalam bukunya, Evaluation and Legal Theory, Dickson mengajukan gagasan tentang "teori evaluasi tidak langsung" (indirect evaluative legal theory). Ide Dickson di sini adalah mengemukakan abstraksi dari penubuhan teori tentang hakikat hukum yang memenuhi kriteria kesuksesan akademis-ilmiah teori. Dickson berusaha menindaklanjuti ajaran positivistik Raz tentang pencirian teori hukum. Dengan berargu-men di dalam dan menurut pandangan Raz, metodologi Dickson mem-berikan penilaian kritis terhadap tingkat kesuksesan secara khusus terhadap dua teori hukum, yakni dari Finnis dan Dworkin. Di dalam sebuah artikel kuncinya, Dickson memperluas jangkauan kritiknya itu dengan mensurvei teori-teori hukum yang, dengan satu dan berbagai cara, menanggapi dan berupaya melampaui teori Hart yang metode berfilsafat hukumnya bercorak deskriptif, sebagaimana yang tampak dalam paparan Postscript Hart. Mengikuti cara berpikir dari survei kritis Dickson tersebut, dan koheren dengan pandangan tulisan ini, telaah yang dikemukakan di sini justru hendak menyentuh dimensi metode filsafat hukum normatif. Dasar argumentasinya adalah karena metodologi normatif tersebut seolah-olah didudukan dalam ranah pergulatan metodologi filsafat hukum sebagai pandangan yang harus keliru, meski sebenarnya tidak perlu dilawankan dengan metodologi deskriptif a la Hart.

Berdasarkan kerangka pokok bahasan di atas, ada dua hal yang paling relevan dalam teks Dickson tentang survei metodologi tersebut. Hal pertama adalah yang berkenaan dengan peran evaluasi dalam kegiatan berfilsafat hukum dan hal kedua tentang kategori-kategori yang dipakai dalam menjelaskan hakikat hukum. Dalam terang debat Hart/ Dworkin, dapat dikatakan bahwa kedua bagian itu menunjuk pada karakter evaluatif dari filsafat hukum yang diuji berhadapan dengan karakter deskriptif dalam teori Hart. Lebih spesifiknya lagi, hasil survei Dickson menunjukkan bahwa argumentasi Dworkin yang mengkritik metodologi Hart (hakikat hukum dapat dijelaskan dengan metode "interpretasi konstruktif," bukan dengan metode penjelasan kriteria 
semantik atas pemahaman konsep-konsep hukum yang digunakan orang-orang yang kompenten) dianggap meleset. Apa yang membuat metodologi normatif dan teori interpretasi Dworkin sedemikian disangkakan keliru di hadapan tradisi pemikiran metodologi deskriptif dan positivisme hukum Hart? Dari survei Dickson, perlu digarisbawahi bahwa perdebatan metodologi filsafat hukum tidaklah bersifat dikotomis antara pandangan Hart(-ian) dan Dwork(-ian) belaka. Ini menegaskan pokok tentang pluralisme metodologi yang telah disebut sebelumnya.

Sebuah kemungkinan jawaban atas pertanyaan di atas adalah bahwa pengembangan metodologi deskriptif Hart(-ian) senantiasa berkomitmen pada positivisme hukum yang memisahkan hukum dari moralitas. Tapi bagaimana dengan pengembangan metodologi evaluatif Dworkin(-ian)? Bagaimana jika gagasan tentang makna, tugas, dan corak filsafat hukum dari teori hukum interpretatif Dworkin dilihat sesuai dengan komitmennya tentang keterkaitan hukum dan moralitas? Seturut situasi palingan metodologis, patut dikritisi perihal sejauh apa metodologi normatif filsafat hukum yang memandang hakikat hukum yang terhubung dengan moralitas.

Coleman mengemukakan kajian yang gamblang perihal problematika di atas. Melalui sejumlah teksnya, ia mengajukan tesis bahwa metodologi filsafat hukum dapat melampaui tesis pemisahan hukum dan moralitas. Komitmen Coleman adalah pada pandangan positivistik Raz tentang proses dan kegiatan teoretisasi hukum yang sesungguhnya juga mengacu pada aspek normatif dari hukum, yakni klaim atas kewenangan yang legitim (legitimate authority). ${ }^{32}$ Dengan mempertimbangkan gagasan Coleman tersebut, kita dapat melihat kemungkinan bagi suatu makna kegiatan berfilsafat hukum yang normatif-evaluatif, yakni upaya mengkonstruksi teori tentang corak hukum yang mengacu pada nilainilai.

32 Jules L. Coleman, “Law and Political Morality." The American Philosophical Association on Philosophy and Law 6 (2007): 10-13. 
Coleman menggambarkan duduk perkara dari pergulatan metodologi deskriptif dan normatif dalam kaitannya dengan masalah filosofis hubungan hukum dengan moralitas. ${ }^{33}$ Posisinya jelas, yakni membela metodologi deskriptif namun sekaligus hendak melampaui pemisahan dikotomis hukum dan moralitas. Seperti yang dijelaskan Coleman, metodologi deskriptif menunjuk pada kegiatan berfilsafat hukum yang menguraikan makna hukum secara analitis tanpa perlu mengacu pada substansi, nilai, atau cita-cita dari keberadaan (aplikasi praktis) hukum. Metodologi normatif adalah yang sebaliknya. Namun, seperti yang ditunjukkan Coleman, duduk perkara perdebatan metodologi deskriptif dan normatif sangat bernuansa, yakni menyangkut klaim-klaim tentang status, ruang lingkup, dan koherensi dari makna sifat deskriptif dan normatif. ${ }^{34}$

Karena keterbatasan, di sini tidak akan ditinjau secara rinci paparan Coleman. Setidaknya ada dua pokok dari pandangan Coleman yang penting untuk ditelaah dalam rangka menelusuri kemungkinan bagi karakter teoretisasi hukum. Pertama, topologi filsafat hukum yang deskriptif dan normatif berkonsentrasi pada upaya meneorikan hukum secara adekuat. Dengan ini, variabel-variabel tentang metode, khususnya analisis konseptual dan juga evaluasi nilai, diukur tingkat memadainya. Kedua, misi Coleman adalah menegaskan konsistensi antara metodologi deskriptif dan klaim tentang keterjalinan hukum dengan moralitas. Berdasarkan dua pokok ini, kita dapat mengungkap sebuah alternatif gagasan bagi pertanyaan tentang pengembangan teori hukum Dwork(ian) di atas. Apabila kita membalik pokok yang kedua sehingga metodologi normatif konsisten dengan klaim keterjalinan hukum dan moralitas, apa yang menandai atau yang menjadi konsentrasi dari kegiatan

33 Jules L. Coleman, "Beyond the Separability Thesis: Moral Semantics and the Methodology of Juriprudence." Oxford Journal of Legal Studies 27 (2007): 581-582, 597, 600 .

34 Jules L. Coleman, "Methodology," in The Oxford Handbook of Jurisprudence and Philosophy of Law, eds. Jules L. Coleman, Kenneth Einar Himma, and Scott J. Shapiro (Oxford: Oxford University Press, 2004), p. 313-352. 
filsafat hukum, di samping kriteria adekuat bagi sebuah teori tentang makna hukum?

Coleman sebenarnya telah menyinggung pertanyaan ini ketika ia mencoba mengkritisi pemikiran konvensional filsafat hukum. Kritik Coleman adalah bahwa dalam filsafat hukum pandangan substantif dan metodologis tidak serta-merta bergandengan. ${ }^{35}$ Namun, demikian Coleman, pemikiran Dworkin justru menunjukkan bahwa pandangan substantif dan metodologisnya bergandengan. Secara substantif, Dworkin memandang bahwa filsafat hukum bertugas mengungkapkan dasar-dasar hukum (grounds of law), yakni landasan kebenaran bagi keberadaan hukum. Maka tugas filsafat hukum adalah mengemukakan nilai-nilai yang menjustifikasi (evaluasi) peran hukum dalam praktik penerapannya pada dan bagi hidup individu-individu di masyarakat. Secara metodologis, teori tentang hakikat atau esensi dari hukum dikonstruksikan melalui proses interpretasi terhadap konsep yang mengandung atau sesuai dengan nilai-nilai yang ada pada pandangan substantif itu. Pertanyaan di akhir paragraf sebelumnya kini dapat dirumuskan secara berbeda: model kegiatan filsafat hukum yang seperti apa atau bagaimana yang secara substantif dan metodologis bersifat normatif?

Pertanyaan di atas akan ditinjau secara khusus di sub-bagian berikutnya. Sebagai penutup bagian ini hendak ditegaskan bahwa pertanyaan tersebut telah mendapat tempat dalam sejumlah kajian yang serius filsafat hukum kontemporer. ${ }^{36}$ Kajian-kajian itu menunjukkan sebuah benang

35 Jules L. Coleman, “The Architecture of Jurisprudence.” The Yale Law Journal 121 (2011): 34-41.

36 Setidaknya ada tiga contoh pandangan cendikiawan filsafat hukum yang, secara langsung atau tidak langsung, menindaklanjuti problematika tentang model kegiatan filsafat hukum di atas. Kendati bukan merupakan sebuah tubuh teoritis yang terwujud dari perkembangan karya tekstual yang utuh, ketiganya itu sedikit atau banyak memperlihatkan implikasi dari palingan metodologis berdasarkan debat Hart/Dworkin. Pandangan pertama berasal dari teks Michel Rosenfeld. Di situ, ia mempertanyakan peran dari cara berpikir, pokok bahasan, dan metode ranah disiplin filsafat yang inheren dalam ranah hukum. Michel Rosenfeld, "Philosophy in Law? A Legal Philosophical Inquiry." Cardozo Legal Studies Research Paper No. 346. https://cardozo.yu.edu/faculty-intellectual-life/\%E2\%80\%9Cphilosophy-law-legalphilosophical-inquiry\%E2\%80\%9D, diakses pada 18 Desember 2017. Pandangan 
merah, yakni bahwa problematika tentang karakter serta langkah-langkah melakukan kegiatan filsafat hukum dalam kerangka keterkaitan hukum dan moralitas. Ketiganya itu memperlihatkan arus pemikiran popular yang berpaling pada pertanyaan metodologis setelah debat Hart/ Dworkin. Di titik inilah, kita pantas untuk menimbang ulang situasi pasca debat Hart/Dworkin.

\section{PELAJARAN SETELAH DEBAT HART/DWORKIN}

Pada bagian ini kita akan menimbang ulang makna dari debat Hart/ Dworkin dengan bertolak dari pertanyaan yang mengemuka di bagian sebelumnya, yakni: model kegiatan filsafat hukum seperti apakah yang bercorak normatif-evaluatif? Sebagaimana yang telah ditunjukkan, terdapat beberapa contoh kecenderungan orientasi pemikiran metodologis berdasarkan pertanyaan tersebut. Namun sejauh apa debat Hart/ Dworkin masih relevan dan berpengaruh di situ? Apakah debat Hart/ Dworkin itu keliru, pantas untuk dianggap kadaluarsa, dan karenanya segala perdebatan filosofis tentang hakikat hubungan hukum dan moralitas sebaiknya disudahi saja, seperti yang dikatakan Scott Hershovits? ${ }^{37}$

Bagian ini mengungkapkan bahwa pemodelan kegiatan berfilsafat hukum yang bercorak tersebut dimungkinkan justru berkat acuan kepada kerangka debat Hart/Dworkin. Argumen yang diajukan di sini adalah bahwa debat Hart/Dworkin makin menjadi sentral dari pembahasan

kedua mengemuka dari gagasan Dan Priel. Priel menangkap kesan bahwa para penstudi filsafat hukum, seperti Dickson, sudah terlampau menitikberatkan pada kecanggihan metode filsafat hukum itu sendiri. Akibatnya, pemaknaan metode deskripsi dan evaluasi sendiri mengandung sejumlah kekeliruan mendasar. Dan Priel, "Description and Evaluation in Jurisprudence." Law and Philosophy 29 (2010): 633-667. Adapun pandangan yang ketiga datang dari argumen duet David Plunkett dan Scott Shapiro. Pada intinya, mereka memandang bahwa kajian filsafat hukum adalah perpanjangan tangan atau cabang dari kajian "metalegal". David Plunkett and Scott Shapiro, "Law, Morality, and Everything Else: General Jurisprudence as a Branch of Metanormative Inquiry." Ethics 128 (October 2017): 37-68. Dalam pandangan Plunkett dan Shapiro, yang disebut terakhir itu paralel dengan kajian metaetika.

37 Scott Hershovits, “The End of Jurisprudence." The Yale Law Journal 124 (JanuaryFebruary 2015): 1160-1199. 
masalah metodologi filsafat hukum, khususnya di dalam konteks pembaruan makna debat tersebut dengan dipublikasikannya esai kuliah Dworkin yang berjudul "Hart's Posthumous Reply." Konteks inilah yang menegaskan situasi pasca debat Hart/Dworkin dan yang makin menunjukkan bahwa kerangka debat tersebut sangat relevan untuk menemukan arti aktivitas ber-filsafat hukum, yakni sebuah refleksi atas hukum sebagai praktik institusional yang dasar keabsahannya (legalitas) mengalir dari kekuatan mengikatnya (normativitas), yakni hormat atas nilai kesetaraan individu-individu warga negara.

Untuk menguraikan argumen tersebut, bagian ini disajikan sebagai berikut. Pertama akan diulas esai kuliah Dworkin di atas dengan mengkaitkannya pada beberapa teks kunci lain karangan Dworkin tentang metodologi filsafat hukum dan debatnya dengan Hart. Langkah ini akan menunjukkan sisi lain dari posisi metodologis Dworkin yang hampir jarang disentuh, di samping konsepsi-konsepsinya yang sudah umum dikategorikan oleh para kritikusnya, seperti Coleman dan Leiter. Lantas, hasil ulasan tersebut akan didiskusikan dengan beberapa pandangan kritis mengemukakan gambaran kegiatan melakukan filsafat hukum yang memikat, menarik, dan atraktif berdasarkan teori Dworkin. Dengan dua langkah telaah tersebut akan tampak bahwa menurut Dworkin filsafat hukum pada hakikatnya adalah sebuah kegiatan menalar moral.

Teks "Hart's Posthumous Reply" dapat dipahami dengan mendudukannya pada konteks debat Hart/Dworkin dan situasi palingan metodologis. Teks tersebut adalah esai Dworkin yang berisi tanggapannya terhadap tulisan Postscript Hart. Nicos Stavropoulos menyatakan bahwa penerbitan ulang teks tersebut secara meluas (alias tidak lagi sekadar terbatas pada kalangan tertentu dalam bentuk manuskrip kuliah) berkontribusi bagi redefinisi debat Hart/Dworkin. ${ }^{38}$ Dalam arti itu, ada dua pokok perlu digarisbawahi dari pandangan Stavropoulos bagi

38 Nicos Stavropoulos, "The Debate that Never Was." Harvard Law Review 130 (June 2017): 2082-2095. 
pembahasan bagian ini. Pertama, teks "Hart's Posthumous Reply" menegaskan bahwa debat Hart/Dworkin adalah tentang “...pertanyaan tentang peran moralitas dalam penjelasan tentang makna hukum."39 Kedua, teori hukum Dworkin mengemukakan suatu cara berpikir hukum interpretatif yang bergerak selangkah lebih maju atau di depan daripada cara berpikir hukum positivistik dalam menjelaskan poin tentang peran moralitas tersebut. ${ }^{40}$

Dengan menimbang dua pokok dari ulasan Stavropoulos, dapat dilihat bahwa teks "Hart's Posthumous Reply" menegaskan eksistensi filsafat hukum yang khas yang berdasarkan pada suatu metodologi normatif-evaluatif. Hal tersebut makin jelas ketika teks tersebut dikaitkan dengan perkembangan pemikiran Dworkin setelah publikasi Postscript Hart. Pada bagian ini, pembahasan difokuskan hanya pada dua teks Dworkin yang lain, yaitu artikel "Hart's Postscript and the Character of Political Philosophy" dan teks pidato Dworkin di Universitas Cape Town. ${ }^{41}$

Ketiga sumber pustaka Dworkin tersebut menunjukkan bahwa posisi metodologi normatif-evaluatif adalah bagian dari sebuah alur refleksi filosofis yang sistematis. Seperti yang Dworkin kemukakan, gagasan tentang konsep hukum dan filsafat hukum yang interpretatif mengarah pada kritik metafisis dan metaetis tentang kebenaran nilai dan moral. Berdasarkan pandangan Dworkin tentang proses memahami hukum

39 Nicos Stavropoulos, "The Debate that Never Was.": 2086.

40 Nicos Stavropoulos, "The Debate that Never Was.": 2093.

41 Artikel "Hart's Postscript and the Character of Political Philosophy" adalah bagian dari kumpulan karangan Dworkin di buku Justice in Robes. Ronald Dworkin, Justice in Robes (Cambridge, Massachusetts: The Belknap Press of Harvard University Press, 2006). Teks pidato Dworkin yang dimaksud terdapat di dalam buku kumpulan tulisan hasil konferensi tentang pemikiran Dworkin, lih: François du Bois ed., The Practice of Integrity: Reflections on Ronald Dworkin and South African Law (Cape Town: Juta \& Co Ltd, 2005). Adapun teks Dworkin yang lain yang sebenarnya juga relevan di sini adalah artikelnya tentang kebenaran objektif, lih: Ronald Dworkin, "Objectivity and Truth: You'd Better Believe it." Philosophy and Public Affairs 25 (Spring, 1996). Juga buku terakhir Dworkin sebelum ia wafat, Justice for Hedgehogs. Ronald Dworkin, Justice for Hedgehogs (Cambridge, Massachusetts: The Belknap Press of Harvard University Press, 2011). 
sebagai bagian dari moralitas politis, dalam alur berpikir tersebut tampak bahwa metodologi filsafat hukum yang dimaksud mengacu pada kritik metafisis dan metaetis tersebut, yang lantas melahirkan ajaran tentang etika praktis dalam kehidupan sesama individu manusia dan prinsip politis (tentang keadilan, demokrasi, dan kebebasan) dalam kehidupan sosial. $^{42}$

Menurut alur refleksi di atas, argumen metodologis Dworkin dapat dirangkum sebagai berikut. ${ }^{43}$ Bahwa kegiatan berfilsafat hukum bertujuan untuk membuat keputusan nilai (value judgenment) dalam rangka menemukan prinsip yang tertanam dalam hukum yang seharusnya diterapkan atau berlaku. Argumen tersebut mengacu pada ide bahwa kajian tentang hukum adalah bagian dari kajian tentang nilai karena baik hukum maupun kajian tentangnya terletak dalam jaring kehidupan bersama manusia yang ada di setiap konteks budaya.

Dalam "Hart's Posthumous Reply," argumen metodologis di atas tampak diartikulasikan di dalam bagian penjelasan tentang hakikat teori (atau filsafat) hukum. ${ }^{44}$ Bagian ini merupakan bagian pertama dari enam bagian tanggapan Dworkin terhadap isi Postscript Hart, menurut sistematika tulisan Postscript Hart itu sendiri. Berdasarkan ide bagian pertama "Hart's Posthumous Reply" tersebut, maka argumen metodologis Dworkin tersebut menunjukkan pandangannya tentang hakikat filsafat hukum, yakni sebagai kegiatan menginterpretasi argumen-argumen normatif tentang hukum yang dihasilkan juga dari penafsiran. Jadi, antara teori tentang aktivitas menalar hukum dan praktik penalaran hukum yang dilakukan oleh para ahli hukum tidak memiliki garis pemisah.

Pokok tentang hubungan teori hukum (filosofis) dan penalaran hukum (praktis) di atas merupakan tesis utama Dworkin mengenai haki-

42 Ronald Dworkin, "Keynote Address," in The Practice of Integrity: Reflections on Ronald Dworkin and South African Law, ed. François du Bois (Cape Town: Juta \& Co Ltd, 2005), p. 1-9.

43 Ronald Dworkin, “Keynote Address," p. 4, 12-13.

44 Ronald Dworkin, “Hart's Posthumous Reply." Harvard Law Review 130 (June 2017): 2096-2130. 
kat filsafat hukum. Kegiatan melakukan filsafat hukum di sini digambarkan sebagai suatu peleburan antara teori hukum dan praktik. Dworkin menekankan bahwa gambaran hakikat filsafat hukum seperti itulah yang menjadi poin perdebatannya dengan isi Postscript Hart. ${ }^{45}$ Dalam kerangka palingan metodologis Marmor di bagian sebelumnya, peleburan tersebut menunjuk pada afirmasi bahwa interpretasi teori-teori hukum pada tatanan pertama (dalam penalaran hukum praktis) niscaya bersifat evaluatif. Artinya, upaya menjelaskan esensi hukum secara konseptual terkandung di dalam upaya menjawab masalah hukum yang terjadi yang dihadapi orang-orang.

Tesis peleburan teori dan praktik di atas menyangkut pandangan Dworkin mengenai tujuan kegiatan filsafat hukum. Menurutnya, kajian filsafat hukum bertujuan untuk menelusuri pertanyaan tentang "syaratsyarat kebenaran dari proposisi-proposisi hukum yang diklaim dalam sebuah perkara" (truth conditions of legal propositions). Dworkin membedakan konsepsi tujuannya ini dari konsepsi filsafat hukum analitik, yakni yang bertujuan untuk menggali esensi dari entitas sistem hukum. Dalam tiga teks Dworkin yang menjadi fokus bahasan di sini, tujuan filsafat hukum dalam arti itu, bersama dengan tesis peleburan teori dan praktik hukum, dikemukakan berdasarkan kritik metafisis dan metaetis terhadap cara pandang "Archimedian." 46 Maka, model kegiatan filsafat hukum bukanlah kegiatan yang berjarak dan berada di luar lapangan kontroversi klaim yang substansial atas konsep hukum. Dengan kata lain, langkah utama melakukan filsafat hukum adalah dengan mengajukan pemikiran normatif tentang landasan kebenaran dari sebuah klaim yuridis.

Dengan memahami pandangan metodologis di atas seturut alur berpikir Dworkin, dapat dikatakan bahwa setelah debat Hart/Dworkin terdapat suatu orientasi bagi model kegiatan berfilsafat tentang konsep

45 Ronald Dworkin, “Hart's Posthumous Reply”: 2098-2099, 2103.

46 Ronald Dworkin, Justice in Robes, hlm. xx.; Ronald Dworkin, "Keynote Address," p. 10-11; Ronald Dworkin, "Hart's Posthumous Reply": 2097. 
dan sistem hukum, yakni keruntuhan pandangan yang mendikotomikan teori dan praktik hukum. Dalam orientasi tersebut pula ditemukan sebuah kritik mendasar terhadap dua tesis tentang filsafat hukum dan moral yang sejajar dengan dikotomi teori dan praktik, yaitu tesis pemisahan hukum dari moralitas (separation thesis), dan tesis dikotomi antara fakta dan nilai (fact/value dichotomy). Maka, buah pembelajaran setelah debat Hart/Dworkin yang dapat dipetik adalah sebuah pertanyaan: sejauh mana kritik terhadap tesis metafisis, epistemologis, dan etis tentang dikotomi fakta dengan nilai, hukum dengan moralitas, serta teori hukum dengan praktik hukum berlaku secara efektif dalam penelusuran hakikat hukum berdasarkan metodologi yang normatifevaluatif?

Sampai di sini kita telah melihat bahwa model kegiatan filsafat hukum yang melakukan penalaran atas keabsahan hukum (legalitas) menurut justifikasi moral (legitimasi), mengemukakan sebuah problematika metafisis, epistemologis, dan etis tentang hubungan hukum dan moralitas. Setengah abad berlalu sejak debat Hart/Dworkin, situasi filsafat hukum kontemporer kini ditandai secara khusus oleh pertanyaan di atas. Kita telah melihat bahwa pemikiran "teori hukum interpretatif" Dworkin adalah pemicu utama pertanyaan tersebut. Pembacaan atas sejumlah komentator Dworkin sendiri juga menunjukkan arah pemikiran tentang keruntuhan tesis dikotomi dan separasi itu dalam refleksi hakikat hukum. Untuk mendalami hal itu, konsentrasi pembicaraan pasca debat Hart/Dworkin menyentuh problematika gagasan Dworkin tentang cara pandang praktisi hukum secara normatif terhadap konsepsi hukum yang berdasarkan pada konsep interpretasi. ${ }^{47}$

47 W. Bradley Wendel menelusuri hal ini dalam konteks praktik hukum konstitusi dan kebijakan pemerintah eksekutif Amerika Serikat di bawah kepemimpinan Presiden Trump. Wendel menguji ideal "pandangan yang terbaik tentang hukum" Dworkin ketika diterapkan dalam tuntutan etika profesi hukum pejabat negara. W. Bradley Wendel, "Sally Yates, Ronald Dworkin, and the Best View of the Law." Michigan Law Review 115, March 2017: 78-90. Ofer Raban juga mempermasalahkan prasyarat metodologi filsafat hukum Dworkin, yakni mengenai justifikasi moral yang terbaik (best light) atas praktik hukum. Ofer Raban, "Dworkin's Best Light Requirement and the Proper Methodology of Legal Theory." Oxford Journal of Legal Studies 23, Summer 2003: 243-264. 
Berbagai kritik terhadap pandangan Dworkin menunjukkan sebuah masalah utama, yakni hubungan antara penalaran terhadap hukum yang sah menurut kepentingan praktisi hukum dan konsepsi hukum menurut pandangan teoretis para praktisi tersebut. Apakah kedua unsur tersebut terpilah atau melebur satu sama lain dalam proses membangun teori yang dapat menjelaskan hakikat hukum? Lebih lanjut, sejauh apa keterpilahan atau peleburan tersebut dimungkinkan dalam situasi riil keterlibatan dan tanggung jawab kaum profesional hukum pada sebuah masyarakat yang kondisi sosial-politiknya diwarnai keberagaman nilai moral? Dalam pemikiran Dworkin, kegiatan melakukan filsafat hukum ditampilkan sebagai kegiatan yang memukau, seperti ketika seorang ahli hukum terlibat penuh dalam proses hukum demi kepentingan yang terbaik dan yang ideal dari klien dan institusi hukum. ${ }^{48}$ Apakah berdasarkan pernyataan bahwa di dalam praktiknya hukum terkait erat dengan moralitas dapat dihasilkan sebuah penjelasan yang "filosofis, ilmiah, benar, dan objektif" tentang makna abstrak dan umum dari hukum?

Persoalan yang mengemuka di sini tidak bisa dilepaskan dari pengaruh pemikiran Dworkin yang secara khusus menentang model filsafat hukum dari positivisme hukum dan pragmatisme. Pelajaran setelah debat Hart/Dworkin beserta konsekuensi problematisnya adalah sebuah proposal tentang kegiatan melakukan filsafat hukum yang hendak bersanding dan menjadi alternatif bagi model berfilsafat hukum dari dua paham tentang hakikat hukum tersebut. ${ }^{49}$ Sebuah kajian tersendiri sangat layak untuk menjadi tempat menyajikan hamparan masalah dikotomi fakta dengan nilai serta separasi hukum dan moral dalam teori hukum interpretatif Dworkin dalam menjelaskan hakikat hukum.

48 Ronald Dworkin, Justice in Robes, p. 185-186. Elaborasi dari aspek pandangan Dworkin ini dalam kaitannya dengan gagasan metodologi filsafat hukum telah dilakukan oleh Sarah Nason. Lih. Sarah Nason, "Say Something Interesting in Jurisprudence, a Young Scholar's Story," Australian Journal of Legal Philosophy 34 (2009): 193-220.

49 Pokok ini disoroti pula oleh Marmor. Ia memandang bahwa teori hukum interpretatif Dworkin bukan sekadar dimaksudkan untuk menggantikan positivisme hukum (dengan metodologi analitiknya) tapi tampil sebagai "konsepsi filsafat hukum baru" dengan teori interpretasinya. Andrei Marmor, Interpretation and Legal Theory. Second Edition (Oxford and Portland, Oregon: Hart Publishing, 2005), hlm. 8. 


\section{PENUTUP}

Pembahasan di atas setidaknya menunjukkan tiga pokok tentang masalah metodologi filsafat hukum pasca debat Hart/Dworkin. Pertama, bahwa debat Hart/ Dworkin itu, memang, eksis terutama dalam kualitasnya sebagai perdebatan metodologis, yakni yang mempersoalkan model dan langkah-langkah melakukan kegiatan berfilsafat hukum. Kedua, corak dasar perdebatan metodologis dalam kerangka debat Hart/ Dworkin ditandai oleh pertentangan antara dua posisi metodologi, yakni yang normatif-evaluatif dan deskriptif. Berdasarkan pembahasan di atas tampak bahwa masing-masing posisi (dilihat dalam kerangka debat Hart/Dworkin) tersebut memiliki komitmen pada paham filsafat hukum tertentu, yakni positivisme hukum dan teori hukum interpretatif. Adapun pokok ketiga adalah mengenai situasi pasca debat Hart/Dworkin yang ditunjukkan oleh publikasi teks kuliah Dworkin tentang Postscript Hart. Selain menggarisbawahi inti perdebatan Dworkin dengan Hart, teks itu juga mengungkapkan sebuah problematika tentang keruntuhan dua tesis metafisis, epistemologis, dan etis yang sejajar, yaitu dikotomi antara fakta dan nilai serta separasi hukum dan moral dalam langkahlangkah meneorikan hakikat hukum. Pokok yang terakhir ini juga membuka sebuah undangan bagi agenda penelitian filsafat hukum tentang problematika objektivitas nilai etis dalam penalaran moral dan hukum. ${ }^{50}$

Dalam tulisan ini, tiga pokok tersebut merangkai pandangan bahwa perdebatan metodologi menurut debat Hart/Dworkin adalah kontribusi dunia pemikiran hukum bagi pengembangan khazanah filosofis, yakni suatu refleksi atas makna dan hubungan hukum, moralitas, kebenaran, dan pengetahuan secara mendasar dalam konteks praktik hukum di masyarakat.

\section{DAFTAR RUJUKAN}

Baxter, Hugh. “Dworkin's 'One System' Conception of Law and Morality." Boston University Law Review 90 (2010): 857-862.

Bix, Brian. "Methodology in Jurisprudence." JOTWELL (May 19, 2010), http://juris.jotwell.com/methodology-in-jurisprudence/. Diakses pada 6 September 2017 
Untuk Apa Filsafat Hukum? (Tanius Sebastian)

Coleman, Jules L. "Analytic Jurisprudence." Encyclopedia of Philosophy. http:/ / www.encyclopedia.com/humanities/encyclopediasalmanacs-transcripts-and-maps/analytic-jurisprudence. Diakses pada 28 Juli 2017.

- "Beyond the Separability Thesis: Moral Semantics and the Methodology of Jurisprudence." Oxford Journal of Legal Studies 4 (2007): 581-608.

. "Methodology." The Oxford Handbook of Jurisprudence and Philosophy of Law. http://www.oxfordhandbooks.com/view/ 10.1093/ oxfordhb / $9780199270972.001 .0001 /$ oxfordhb9780199270972-e-8. Diakses pada 25 Maret 2017.

- "Law and Political Morality." APA Newsletter on Philosophy and Law 06 (Spring 2007): 7-14.

. "The Architecture of Jurisprudence." The Yale Law Journal 121 (2011): 2-80.

Coyle, Sean. Modern Jurisprudence. A Philosophical Guide. Oxford and Portland, Oregon: Hart Publishing, 2014.

Coyle, Sean and George Pavlakos, eds. Jurisprudence or Legal Science? A Debate about The Nature of Legal Theory. Oxford and Portland, Oregon: Hart Publishing, 2005.

Dickson, Julie. Evaluation and Legal Theory. Portland, Oregon: Hart Publishing, 2001.

. "Methodology in Jurisprudence: A Critical Survey." Legal Theory 10 (2004): 117-156.

. "Why General Jurisprudence is Interesting." Oxford Legal Studies Research Paper 17 (2017). https:/ / papers.ssrn.com/sol3/ papers.cfm?abstract_id=2921820. Diakses pada 19 Juni 2017.

du Bois. François, ed. The Practice of Integrity: Reflections on Ronald Dworkin and South African Law. Cape Town: Juta \& Co Ltd, 2008.

Dworkin, Ronald. "Hart's Posthumous Reply." Harvard Law Review 130 (June 2017): 2096-2130.

- Justice for Hedgehogs. Cambridge, Massachusettes, and London: The Belknap Press of Harvard University Press, 2011.

. Justice in Robes. Cambridge, Massachusettes, and London: The Belknap Press of Harvard University Press, 2006. Press, 1986.

. Law's Empire. Cambridge, Massachusetts: Harvard University 
Green, Leslie. "General Jurisprudence: A $25^{\text {th }}$ Anniversay Essay." Oxford Journal of Legal Studies 25 (2005): 565-580.

Halpin, Andrew. "Methodology." In A Companion to Philosophy of Law and Legal Theory. $2^{\text {nd }}$ Edition, ed. Dennis Patterson. Hoboken, NJ: Wiley-Blackwell, 2010, pp. 607-620.

. "The Methodology of Jurisprudence: Thirty Years Off the Point." Canadian Journal of Law and Jurisprudence 1 (January 2006): 67-68.

Hart, H.L.A. The Concept of Law. Second Edition. Oxford: Oxford University Press, 1994.

Hershovitz, Scott. "The End of Jurisprudence." The Yale Law Journal 124 (2015): 1160-1199.

Lacey, Nicola. A Life of H.L.A. Hart. The Nightmare and The Noble Dream. Oxford: Oxford University Press, 2004.

Langlinais, Alex and Leiter, Brian. “The Methodology of Legal Philosophy." University of Chicago, Public Law Working Paper 407 (2013). https:// ssrn.com/abstract=2167498. Diakses pada 12 April 2017.

Leiter, Brian. "Beyond Hart/Dworkin Debate: The Methodology Problem in Jurisprudence." American Journal of Jurisprudence 48 (2003): 1751. http:// papers.ssrn.com/sol3/papers.cfm?abstract_id=312781. Diakses 9 November 2014.

Marmor, Andrei. Interpretation and Legal Theory. Second Edition. Oxford and Portland, Oregon: Hart Publishing, 2005. Press, 2011.

. Philosophy of Law. Princeton and Oxford: Princeton University . "The Nature of Law." Standford Encyclopedia of Philosophy. https://plato.stanford.edu/entries/lawphil-nature/. Diakses pada 23 Maret 2017.

Nason, Sarah. "Saying Something Interesting in Jurisprudence, a Young Scholar's Story." Australian Journal of Legal Philosophy 34 (2009): 193-220.

Patterson, Dennis. "Notes on the Methodology Debate in Contemporary Jurisprudence. Why Sociologist Might be Interested." Law and Sociology, Vol. 8, pp. 254-258, May 9 (2006). https:// papers.ssrn.com/sol3/papers.cfm?abstract_id=848984. Diakses pada 14 November 2017. 
Plunkett, Daniel dan Scott Shapiro. "Law, Morality, and Everything Else: General Jurisprudence as a Branch of Metanormative Inquiry." Yale Law School, Public Law Research Paper 603 (2017). https:/ / papers.ssrn.com/sol3/papers.cfm?abstract_id=2964089. Diakses pada 28 Juli 2017.

Priel, Daniel. "Description and Evaluation in Jurisprudence." Law and Philosophy 29 (2010): 633-667.

Rappaport, Aaron J. "On the Conceptual Confusion of Juriprudence." Washington University Jurisprudence Review 7 (2014): 77-106.

Shapiro, Scott J. “The 'Hart-Dworkin' Debate: A Short Guide for the Perplexed." http:// papers.ssrn.com/sol3/papers.cfm?abstract_id =968657. Diakses pada 9 November 2014 .

Stavropoulos, Nicos. "The Debate that Never was." Harvard Law Review 130 (2017): 2082-2095.

Tebbit, Mark. Philosophy of Law. An Introduction. London and New York: Routledge, 2005

van Hoecke, Mark, ed. Methodologies of Legal Research. Which Kind of Method for What Kind of Discipline? Oxford and Portland, Oregon: Hart Publishing, 2011.

Wacks, Raymod. Understanding Jurisprudence. An Introduction to Legal Theory. Third Edition. Oxford: Oxford University Press, 2012. 